ONTOLOGY OF PRODUCTION 
ASIA-PACIFIC

CULTURE, POLITICS, AND SOCIETY

Editors

Rey Chow, Michael Dutton,

H. D. Harootunian, and Rosalind C. Morris 


\section{ONTOLOGY OF PRODUCTION}

Nishida Kitarō

Translated and with

an Introduction by

William Haver

DUKE UNIVERSITY PRESS

DURHAM AND LONDON

2012 
๑) 2012 Duke University Press

All rights reserved

Printed in the United States of America

on acid-free paper @

Designed by Nicole Hayward

Typeset in Adobe Garamond Pro by

Tseng Information Systems, Inc.

Library of Congress Cataloging-in-

Publication Data appear on the

last printed page of this book. 